\title{
Relationship between DNA Content and Spore Volume in Sixteen Isolates of Verticillium lecanii and Two New Diploids of $V$. dahliae $(=V$. dahliae var. longisporum Stark)
}

\author{
By C. W. JACKSON† AND J. B. HEALE* \\ Department of Biology, Queen Elizabeth College (University of London), Campden Hill Road, \\ London W8 7 AH, UK
}

(Received 20 May 1985; revised 2 August 1985)

\begin{abstract}
Sixteen wild-type isolates of Verticillium lecanii from different insects and non-insect hosts, soils and locations exhibited a wide range in spore volumes, from $2.18 \mu \mathrm{m}^{3}$ to $18.25 \mu \mathrm{m}^{3}$, as recorded by Coulter counter analysis. A cold hydrolysis technique for Feulgen DNA microdensitometry indicated that all the isolates were haploid. Two wild-type strains of $V$. dahliae, from rape and sugarbeet from Sweden, were shown to be stable diploids by the criteria of conidial volume and relative DNA content. After treatment with $p$-fluorophenylalanine, both $V$. dahliae strains produced haploid segregants with half the conidial volume and relative DNA content of the original parents. Both diploid strains are regarded as new records for $V$. dahliae var. longisporum (Stark).
\end{abstract}

\section{INTRODUCTION}

Verticillium lecanii (Zimm.) Viegas and $V$. dahliae Kleb. are widespread deuteromycete fungi. $V$. lecanii includes isolates with the ability to parasitize insects (Burges, 1981), although some isolates hyperparasitize fungi (Hall, 1980) and others are saprophytic. Due to its entomopathogenic nature, certain isolates of $V$. lecanii have been developed as commercial microbial insecticides by Microbial Resources Ltd (formerly Tate and Lyle Ltd), against glasshouse aphids and whiteflies (Hall, 1981). V. dahliae is a vascular wilt plant pathogen (Isaac, 1949), attacking a wide range of crops. Both species reproduce asexually via the production of verticillately borne, single-celled, uninucleate conidia (Domsch et al., 1980).

Heterokaryosis and the parasexual cycle in imperfect plant pathogenic fungi are frequently proposed as mechanisms involved in the origin of new pathogenic races (Day, 1960; Tinline \& MacNeill, 1969). Buxton (1956) found that several haploid segregants from a heterozygous diploid, formed between auxotrophic strains of Fusarium oxysporum f. sp. pisi, were recombinant for both auxotrophic markers and pathogenicity. As early as 1879 , Reinke \& Berthold reported anastomosing germ-tubes of plant pathogenic species of Verticillium. Schreiber \& Green (1966) observed anastomosis between hyphae from germinating conidia of $V$. albo-atrum $(=V$. dahliae sensu Isaac, 1949); later Singh (1972) observed hyphal anastomosis and nuclear migration in $V$. lecanii. These reports indicated the possibility of heterokaryon formation in the wild by both species studied here. The parasexual cycle has been demonstrated in the laboratory for both $V$. dahliae (Hastie, 1970; Typas \& Heale, 1976) and $V$. lecanii (Jackson \& Heale, 1983). Evidence for the parasexual cycle in the wild is still limited although large-spored, wild-type, diploids have been reported in various fungi, e.g. in Aspergillus niger and A. nidulans (Nga et al., 1975; Upshall, 1981), in V. albo-atrum, V. dahliae, V. tricorpus (Hastie \& Heale, 1984) and in V. dahliae var. UK.

$\dagger$ Present address: Department of Biology, University of Southampton, Southampton, Hampshire SO9 5NH, 


\section{Table 1. Original host and geographical location of Verticillium isolates}

The CBS isolates of $V$, lecanii were kindly supplied by Dr W. Gams, Centraalbureau voor Schimmelcultures, Baarn, The Netherlands. Isolates $\mathrm{C} 3$ and $\mathrm{C} 42$ of $V$. lecanii were kindly supplied by Dr R. A. Hall, Glasshouse Crops Research Institute, Littlehampton, UK. $V$. dahliae isolates SOS and SBS were kindly supplied by Dr A. A. Bell and Dr J. Puhalla, National Cotton Pathology Research Laboratory, College Station, Texas, USA. Isolate CMI 21176 was obtained from the Commonwealth Mycological Institute, Kew, UK. V. dahliae var. longisporum is our laboratory strain.

\begin{tabular}{|c|c|c|}
\hline Isolate & Original hos. & $\begin{array}{l}\text { Geographical } \\
\text { location }\end{array}$ \\
\hline \multicolumn{3}{|l|}{ V. lecanii } \\
\hline C3 & Macrosiphoniella sanborni (aphid) & UK \\
\hline $\mathrm{C} 42$ & Myzus persicae (aphid) & India \\
\hline CBS $318.70 \mathrm{~K}$ & Nematus pavidus (sawfly-nymph) & Unknown \\
\hline CBS $318.70 \mathrm{D}$ & Pristiphora abietina (sawfly) & Czechoslovakia \\
\hline CBS 170.76 & Carpocapsa pomonella (codling moth) & Poland \\
\hline CBS 384.35 & Lecanium coryli (scale) & Czechoslovakia \\
\hline CBS $318.70 \mathrm{~L}$ & Diprion pini & E. Germany \\
\hline CBS 140.60 & Wooden floor & Netherlands \\
\hline CBS 446.54 & Soil & Zaire \\
\hline CBS 132.56 & Soil & Zaire \\
\hline CBS $413.70 \mathrm{~A}$ & Tuber maculatum (truffle) & Netherlands \\
\hline CBS 123.42 & Citbotium schiedei (fern) & Netherlands \\
\hline CBS 531.72 & Salvinia rotundifolia (aquatic plant) & Poland \\
\hline CBS 455.70A & Saissetia olea & Morocco \\
\hline CBS 455.70B & Unknown & USSR \\
\hline CMI 21176 & Unknown & Unknown \\
\hline$V$. dahliae var. longisporum & Horse-radish & Germany \\
\hline V. dahliae SOS & Rape & Sweden \\
\hline$V$. dahliae SBS & Sugarbeet & Sweden \\
\hline
\end{tabular}

longisporum (Stark, 1961; Ingram, 1968). Further, Typas \& Heale (1976) observed segregation for acriflavine resistance in a large-spored $V$. albo-atrum strain from tomato, which they regarded as evidence for a heterozygous diploid occurring in the wild.

A doubling in spore size is often regarded as evidence for a doubling in the nuclear DNA content, e.g. for Puccinia graminis (Williams \& Mengden, 1975), Aspergillus nidulans (Clutterbuck, 1969), V. nigrescens, V. nubilum, V. albo-atrum (Tolmsoff, 1972) and V. dahliae (Typas \& Heale, 1977). In work on genetic recombination with $V$. dahliae and $V$. albo-atrum, Typas (1983) used conidial length data to differentiate between diploids, prototrophic haploid recombinants and aneuploids. Feulgen DNA microdensitometry has previously been used for DNA estimations of $V$. dahliae and $V$. albo-atrum conidia (Typas \& Heale, 1980), but the hot $\left(60^{\circ} \mathrm{C}\right)$ hydrolysis method used did not always produce consistent results.

An earlier paper (Jackson et al., 1985) described factors associated with virulence in 18 different isolates of $V$. lecanii, ranging from highly pathogenic to saprophytic types. In this paper, we report DNA microdensitometry determinations using a cold hydrolysis procedure on 16 isolates exhibiting a considerable range in spore size. In view of a report by Puhalla \& Hummel (1983) that two large-spored isolates of $V$. dahliae from rape and sugarbeet failed to mutate after UV treatment, these two isolates and an established stable diploid strain of $V$. dahliae ( $V$. dahliae var. longisporum) were also included in the investigation.

\section{METHODS}

Fungal isolates. Sixteen wild-type prototrophic isolates of $V$. lecanii and three of $V$. dahliae were used (Table 1). Single-spore isolations were made from each and stock cultures maintained on complete agar slopes in the dark at $4^{\circ} \mathrm{C}$.

Media. Complete medium (CM) was as described previously (Jackson et al., 1985). Autoclaving was at $120^{\circ} \mathrm{C}$ for $20 \mathrm{~min}$. To prepare haploidization medium, CM was cooled to $40^{\circ} \mathrm{C}$ and a filter-sterilized solution of $p$ fluorophenylalanine added prior to pouring (final concentration: $0.0116 \%, \mathrm{w} / \mathrm{v}$ )

Conidial volume. Conidia were harvested with $10 \mathrm{ml}$ sterile distilled water from semi-synchronous 7 -d-old spread-plate cultures, incubated at $22-24^{\circ} \mathrm{C}$ in the dark. Conidial suspension $\left(0.2 \mathrm{ml}, 1 \times 10^{6}-1 \times 10^{7} \mathrm{ml}^{-1}\right)$ was 


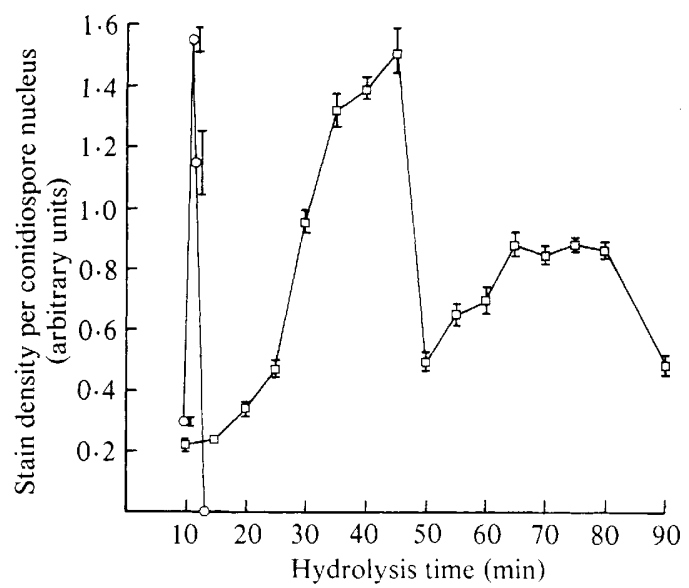

Fig. 1. Effect of 'cold' hydrolysis $\left(5 \mathrm{M}-\mathrm{HCl}, 26^{\circ} \mathrm{C}\right)\left([\square)\right.$ and 'hot' hydrolysis $\left(1 \mathrm{M}-\mathrm{HCl}, 60^{\circ} \mathrm{C}\right)(\mathrm{O})$ on the intensity of Feulgen staining of nuclei of conidia of $V$. lecanii. The bars indicate SD $(n=50)$.

added to $18 \mathrm{ml}$ Isoton solution $\left(8 \mathrm{~g} \mathrm{NaCl}, 0.2 \mathrm{~g} \mathrm{KCl}, 1 \cdot 15 \mathrm{~g} \mathrm{Na}_{2} \mathrm{HPO}_{4}, 0 \cdot 2 \mathrm{~g} \mathrm{KH}_{2} \mathrm{PO}_{4}\right.$ and $1 \mathrm{~g} \mathrm{NaN}_{3}$ in 1 litre of water) in a plastic cuvette. Volume measurements were made with a Coulter counter (Typas \& Heale, 1977) mode] ZB1, fitted with a probe with a $30 \mu \mathrm{m}$ diameter orifice, connected to a Coulter Channelyzer C100 (Coulter Electronics Ltd) and interfaced to a computer programmed to calculate mean values and standard error. Accuracy was checked by using latex granules of known volume.

Feulgen staining. The methods of Heale et al. (1968) and Typas \& Heale (1980) proved unsatisfactory for optimum staining of $V$. lecanii conidia. The following technique was developed by varying fixation, hydrolysis and staining procedures.

A conidial suspension of one test isolate was dried onto one end of a coverslip $(22 \times 50 \mathrm{~mm})$, spores from a control strain being applied to the opposite end. The coverslips had been previously coated with a gelatin-based (Jensen, 1962) adhesive $(5 \mathrm{~g}$ gelatin and $0.5 \mathrm{~g}$ chromic potassium sulphate dissolved in $1000 \mathrm{ml}$ distilled water at $30-38^{\circ} \mathrm{C}$ ).

Fixation was done for $5 \mathrm{~min}$ in freshly prepared Helly`s solution $(5 \mathrm{~g}$ mercuric chloride and $3 \mathrm{~g}$ potassium dichromate in $100 \mathrm{ml}$ distilled water; just before use, $1 \mathrm{ml}$ formaldehyde was added). After washing in distilled water, the conidia were hydrolysed at $26^{\circ} \mathrm{C}$ in $5 \mathrm{~m}-\mathrm{HCl}$ for $45 \mathrm{~min}$; the coverslips were transferred to freshly made Schiff's solution (Fox, 1969, slightly modified), prepared by adding $1.5 \mathrm{~g}$ basic fuchsin (Gurr) and $3.8 \mathrm{~g}$ sodium metabisulphite to $200 \mathrm{ml} 0 \cdot 15 \mathrm{M}-\mathrm{HCl}$. The solution was stirred for $3 \mathrm{~h}$ at room temperature, decolorized with $2 \mathrm{~g}$ activated charcoal and filtered through Whatman no. 1 filter paper. The conidia were stained for 80 min, then washed in sulphur dioxide water $(0.5 \mathrm{~m}$-potassium metabisulphite/1 $\mathrm{M}-\mathrm{HCl}, 2: 1, \mathrm{v} / \mathrm{v})$, dehydrated through an alcohol series and mounted in DPX $(\mathrm{BDH})$, thinned with xylene.

DNA content of conidia. A Vickers M86 scanning microdensitometer was used to record integrated stain densities per nucleus (Typas \& Heale, 1980), compared with an internal control of known ploidy, e.g. V. dahliae var. longisporum, a stable diploid (Ingram, 1968), or V. lecanii isolate C3 (subsequently shown to be haploid). A $\times 100$ oil immersion objective was used, and the microdensitometer settings were: slit width 41.5 units, wavelength $560 \mathrm{~nm}$, orifice size A2 and screening area settings of X1, Y1. Three readings were taken per conidium to calculate the mean. Fifty spores were screened for each treatment, zero levels being checked after every five readings.

\section{RESULTS}

Preliminary experiments involving Feulgen staining suggested that 'hot' hydrolysis $\left(60{ }^{\circ} \mathrm{C}\right.$ in $1 \mathrm{M}-\mathrm{HCl}$ for 10-15 min) similar to that used by Typas \& Heale (1980) for $V$. albo-atrum and $V$. dahliae was unsuitable, and hydrolysis with $5 \mathrm{M}-\mathrm{HCl}$ at $26^{\circ} \mathrm{C}$ for $45 \mathrm{~min}$ was preferable. The reason for this was indicated by the calibration curves of hydrolysis time against amount of Feulgen stain per conidial nucleus, recorded on the scanning microdensitometer (Fig. 1). For both types of hydrolysis, the optimal values were about the same for the two methods, but the 'hot' hydrolysis optium occurred after only $12 \mathrm{~min}$ and persisted for $1 \mathrm{~min}$ at the most. 
Table 2. Relationship between conidial volume and ploidy level inferred from Feulgen DNA microdensitometry of sixteen isolates of $V$. lecanii

\begin{tabular}{|c|c|c|c|}
\hline Isolate & $\begin{array}{l}\text { Conidial volume } \\
\left(\mu \mathrm{m}^{3} \pm \mathrm{SE}\right)\end{array}$ & $\begin{array}{c}\text { DNA content* } \\
\text { (arbitrary units } \pm \mathrm{SE} \text { ) }\end{array}$ & Ploidy \\
\hline 1. C3 (control) & $4 \cdot 06 \pm 0.22$ & $1.22 \pm 0.02$ & haploid \\
\hline $\begin{array}{ll}\text { 2. } & 123.42 \\
\text { (Control) }\end{array}$ & $2 \cdot 18 \pm 0 \cdot 14$ & $\begin{array}{l}0.99 \pm 0.04 \\
1.19 \pm 0.03\end{array}$ & $\begin{array}{l}\text { haploid } \\
\text { haploid }\end{array}$ \\
\hline 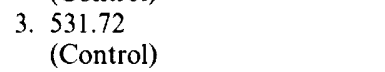 & $3.06 \pm 0.20$ & $\begin{array}{l}1.32 \pm 0.04 \\
1.31 \pm 0.39\end{array}$ & $\begin{array}{l}\text { haploid } \\
\text { haploid }\end{array}$ \\
\hline $\begin{array}{l}\text { 4. } 446.54 \\
\text { (Control) }\end{array}$ & $3.48 \pm 0.17$ & $\begin{array}{l}0.90 \pm 0.08 \\
1.21 \pm 0.05\end{array}$ & $\begin{array}{l}\text { haploid } \\
\text { haploid }\end{array}$ \\
\hline $\begin{array}{l}\text { 5. } 140.60 \\
\text { (Control) }\end{array}$ & $3.91 \pm 0.28$ & $\begin{array}{l}0.87 \pm 0.02 \\
1.07 \pm 0.27\end{array}$ & $\begin{array}{l}\text { haploid } \\
\text { haploid }\end{array}$ \\
\hline $\begin{array}{l}\text { 6. } 413.70 \mathrm{~A} \\
\text { (Control) }\end{array}$ & $4 \cdot 35 \pm 0 \cdot 29$ & $\begin{array}{l}1.05 \pm 0.07 \\
1.08 \pm 0.17\end{array}$ & $\begin{array}{l}\text { haploid } \\
\text { haploid }\end{array}$ \\
\hline $\begin{array}{l}\text { 7. CMI } \\
\text { (Control) }\end{array}$ & $4 \cdot 38 \pm 0 \cdot 29$ & $\begin{array}{l}1.05 \pm 0.06 \\
0.88 \pm 0.03\end{array}$ & $\begin{array}{l}\text { haploid } \\
\text { haploid }\end{array}$ \\
\hline $\begin{array}{l}\text { 855.70B } \\
\text { (Control) }\end{array}$ & $4 \cdot 83 \pm 0 \cdot 22$ & $\begin{array}{l}0.86 \pm 0.04 \\
1 \cdot 12 \pm 0.04\end{array}$ & $\begin{array}{l}\text { haploid } \\
\text { haploid }\end{array}$ \\
\hline $\begin{array}{l}\text { 9. } 170.76 \\
\text { (Control) }\end{array}$ & $5 \cdot 45 \pm 0 \cdot 38$ & $\begin{array}{l}1.08 \pm 0.07 \\
1.12 \pm 0.02\end{array}$ & $\begin{array}{l}\text { haploid } \\
\text { haploid }\end{array}$ \\
\hline 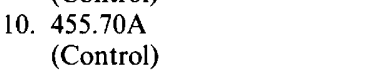 & $5 \cdot 45 \pm 0 \cdot 39$ & $\begin{array}{l}1.01 \pm 0.06 \\
1.19 \pm 0.03\end{array}$ & $\begin{array}{l}\text { haploid } \\
\text { haploid }\end{array}$ \\
\hline $\begin{array}{l}\text { 11. } 318.70 \mathrm{~L} \\
\text { (Control) }\end{array}$ & $5 \cdot 47 \pm 0 \cdot 39$ & $\begin{array}{l}1 \cdot 12 \pm 0.05 \\
1 \cdot 10 \pm 0.05\end{array}$ & $\begin{array}{l}\text { haploid } \\
\text { haploid }\end{array}$ \\
\hline $\begin{array}{l}\text { 12. } 384.35 \\
\text { (Control) }\end{array}$ & $5 \cdot 48 \pm 0 \cdot 37$ & $\begin{array}{l}1.27 \pm 0.39 \\
1.01 \pm 0.05\end{array}$ & $\begin{array}{l}\text { haploid } \\
\text { haploid }\end{array}$ \\
\hline $\begin{array}{l}\text { 13. } 318.70 \mathrm{D} \\
\text { (Control) }\end{array}$ & $5 \cdot 81 \pm 0 \cdot 36$ & $\begin{array}{l}1.43 \pm 0.05 \\
1.10 \pm 0.38\end{array}$ & $\begin{array}{l}\text { haploid } \\
\text { haploid }\end{array}$ \\
\hline 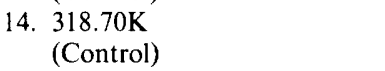 & $6 \cdot 21 \pm 0 \cdot 40$ & $\begin{array}{l}1 \cdot 12 \pm 0.04 \\
1 \cdot 15 \pm 0.01\end{array}$ & $\begin{array}{l}\text { haploid } \\
\text { haploid }\end{array}$ \\
\hline $\begin{array}{l}\text { 15. } 132.56 \\
\text { (Control) }\end{array}$ & $9 \cdot 58 \pm 0 \cdot 52$ & $\begin{array}{l}1.00 \pm 0.36 \\
1.03 \pm 0.07\end{array}$ & $\begin{array}{l}\text { haploid } \\
\text { haploid }\end{array}$ \\
\hline $\begin{array}{l}\text { 16. } 442 \\
\text { (Control) }\end{array}$ & $18 \cdot 25 \pm 1 \cdot 30$ & $\begin{array}{l}1 \cdot 04 \pm 0 \cdot 10 \\
1 \cdot 19 \pm 0 \cdot 05\end{array}$ & $\begin{array}{l}\text { haploid } \\
\text { haploid }\end{array}$ \\
\hline V. dahliae var. longisporum & $16.48 \pm 0.61$ & $2.69 \pm 0.07$ & diploid \\
\hline
\end{tabular}

* The Feulgen DNA microdensitometry values are mean values per conidium from a total of 50 conidia per isolate. For each isolate tested, isolate $\mathrm{C} 3$ was used as an internal control to reduce experimental error.

Hydrolysis at $26^{\circ} \mathrm{C}$ in $5 \mathrm{M}-\mathrm{HCl}$ resulted in a much broader peak of approximately $10 \mathrm{~min}$ for optimal staining, beginning after about $35 \mathrm{~min}$. Slight variability between tests was therefore less of a problem when 'cold' hydrolysis was used. Freshly made Schiff's reagent produced more intense staining than did commercial preparations.

Conidial volumes for 16 different wild-type isolates of $V$. lecanii (Table 2) indicated considerable variability between isolates ranging from $2 \cdot 18 \pm 0.14 \mu \mathrm{m}^{3}$ (isolate 123.42) to $18 \cdot 25$ $\pm 1.3 \mu \mathrm{m}^{3}$ (isolate $\mathrm{C} 42$ ). Feulgen staining revealed that the conidia were regularly uninucleate, and despite the differences in size, DNA microdensitometry values indicated that all were haploid (Table 2). When the 'standard' diploid ( $V$. dahliae var. longisporum) isolate was compared, the values obtained for DNA content were approximately double those for $V$. lecanii isolates $(2.69 \pm 0.07$ units compared with $1.22 \pm 0.02$ for $V$. lecanii), confirming the haploid state of the latter.

The conidial volumes of $V$. dahliae isolates SOS and SBS were $15.04 \pm 0.57 \mu \mathrm{m}^{3}$ and $15.30 \pm$ $0.69 \mu \mathrm{m}^{3}$, respectively, similar to the stable diploid $V$. dahliae var. longisporum $(16.48 \pm$ $0.61 \mu \mathrm{m}^{3}$ ). DNA microdensitometry indicated that all three isolates had approximately the same amount of DNA per conidial nucleus (Table 3 ) and all conidia were uninucleate. When these two test isolates were grown on media containing the haploidizing agent $p$ fluorophenylalanine, sectoring was observed, $V$. dahliae SOS producing fewer sectors than $V$. dahliae SBS. Single-spore isolations from 10 sectors of $V$. dahliae SOS and 15 sectors of $V$. dahliae 
Table 3. Conidial volume and DNA content of natural diploids and induced haploids of $V$. dahliae

\begin{tabular}{lccc}
\multicolumn{1}{c}{ Isolate } & $\begin{array}{c}\text { Conidial volume } \\
\left(\mu \mathrm{m}^{3} \pm \mathrm{SE}\right)\end{array}$ & $\begin{array}{c}\text { DNA content* } \\
\text { (arbitrary units } \pm \mathrm{SE} \text { ) }\end{array}$ & Ploidy \\
$V$. dahliae var. longisporum & $16.48 \pm 0.61$ & $3.56 \pm 0.07$ & diploid \\
$V$. dahliae SOS & $15.04 \pm 0.57$ & $3.49 \pm 0.07$ & diploid \\
$V$. dahliae var. longisporum & $16.48 \pm 0.61$ & $2.75 \pm 0.04$ & diploid \\
$V$. dahliae SBS & $15.30 \pm 0.69$ & $2.81 \pm 0.06$ & diploid \\
$V$. dahliae SBS & $15.30 \pm 0.69$ & $2.55 \pm 0.17$ & diploid \\
$V$. dahliae SBS-1 & $6.44 \pm 0.56$ & $1.20 \pm 0.08$ & haploid \\
$V$. dahliae SBS & $15.30 \pm 0.69$ & $5.08 \pm 0.13$ & diploid \\
$V$. dahliae SBS-2 & $7.87 \pm 0.34$ & $2.29 \pm 0.10$ & haploid \\
$V$. dahliae SOS & $15.04 \pm 0.57$ & $4.57 \pm 0.08$ & diploid \\
$V$. dahliae SOS-1 & $8.13 \pm 0.40$ & $2.24 \pm 0.06$ & haploid
\end{tabular}

\footnotetext{
* The Feulgen DNA microdensitometry values are mean values per conidium from a total of 50 conidia per isolate.
}

SBS were made. One colony from $V$. dahliae SOS (SOS-1) and two from $V$. dahliae SBS (SBS-1 and SBS-2) resulting from these sectors produced relatively small conidia, volume $6-8 \mu \mathrm{m}^{3}$ (Table 3). The nuclear DNA content of the small-spored strains was half the value of the parent isolate from which they were derived (Table 3), thus indicating a reduction to haploidy.

\section{DISCUSSION}

Once the method was established for Feulgen staining, there was still variation in the intensity of the Feulgen reaction. Thus it was essential to have an internal control on the same coverslip as the conidia to be tested, in agreement with the observations of Dhillon et al. (1977). It was also necessary to standardize culture age and environmental conditions, both of which affect spore size (Pelletier \& Aube, 1970). Leslie \& Parbery (1972) showed that $V$. lecanii conidia produced on malt agar had mean lengths of $4.9 \mu \mathrm{m}$, and the addition of $0.158 \mathrm{M}$-fluoride to the medium resulted in conidial lengths of $6.1 \mu \mathrm{m}$. There are numerous reports on factors that influence spore size (Smith, 1965). Even where spore size is a reliable indication of ploidy, spontaneous haploidization of diploids produced in the laboratory (Hastie, 1964; Das \& Ilzuck, 1978) can result in the confusion of haploid recombinants with diploids (Messias \& Azevedo, 1980; Bergeron \& Al-Aidroos, 1982).

The measurement of conidial volume as performed here, using a Coulter counter (Typas \& Heale, 1977), allowed rapid analysis of a large population of spores. For $V$. lecanii, there was a wide variation in mean values between isolates, viz. $2.18 \mu \mathrm{m}^{3}$ to $18.25 \mu \mathrm{m}^{3}$. Results for DNA values indicated that despite such differences, the isolates were all haploid. The microdensitometer readings were about half those obtained for $V$. dahliae var. longisporum, a natural stable diploid (Typas \& Heale, 1980). In additional studies not reported here, auxotrophic and morphological mutants of $V$. lecanii have been obtained with expected frequencies from wildtype parental isolates, following treatment with $N$-methyl- $N^{\prime}$-nitro-nitrosoguanidine or UV irradiation. Cytological studies with Feulgen DNA microdensitometry confirmed that these wild-type isolates of $V$. lecanii were haploid and invariably uninucleate.

Tolmsoff (1983), using an extraction procedure, estimated values of $0.076 \mathrm{pg}$ DNA per nucleus for $V$. dahliae var. longisporum, which agree well with values (approximately half this level) obtained using microdensitometry and a known standard (carp hepatic nuclei) for ungerminated conidia from haploid strains of $V$. dahliae $(0.025-0.030 \mathrm{pg})$ (Typas \& Heale, 1980). By comparison with the microdensitometry data obtained in the present work, we infer that the conidia of $V$. lecanii contain approximately 0.038 pg DNA per nucleus.

The two new naturally occurring diploids of the plant pathogenic species $V$. dahliae studied here, SOS and SBS, in contrast with most other isolates of $V$. dahliae, were large-spored and did 
not yield auxotrophic mutants when treated with UV light by Puhalla \& Hummel (1983). Our results for haploidization, conidium size and relative DNA content per nucleus have established that isolates SOS and SBS are both stable diploids. Until now, the only other proven natural diploid of $V$. dahliae was $V$. dahliae var. longisporum, originally isolated by Stark (1961). On the basis of conidium size, the ability of $p$-fluorophenylalanine to induce small-spored (haploid) forms, the induction of auxotrophic mutants only from the small-spored forms and not from the large-spored form, and the synthesis of types indistinguishable from the large-spored form using haploid auxotrophs, Ingram (1968) concluded that $V$. dahliae var. longisporum was a true diploid. Further studies comparing conidium size (Typas \& Heale, 1977) and relative DNA content between $V$. dahliae var. longisporum and haploid isolates of $V$. dahliae have confirmed this conclusion. There have been other reports of naturally occurring diploids in $V$. dahliae and $V$. tricorpus (Tolmsoff, 1973; Kasyanenko \& Portenko, 1978), but these require additional genetic evidence and DNA determinations before they can be fully accepted. Wild somatic diploids have also been described for other 'normally' haploid plant pathogenic fungi (Caten \& Day, 1977) including Puccinia graminis f. sp. tritici (Williams \& Mengden, 1975) and Aspergillus niger (Nga et al., 1975).

Many deuteromycete fungi can be induced to form diploids under laboratory conditions via the parasexual cycle, using auxotrophic haploid parents (Fincham et al., 1979), species of Verticillium being unexceptional in this respect (Hastie, 1970; Hastie \& Heale, 1984). These heterozygous diploids are mainly unstable, although exceptions do occur (Heale et al., 1981). In contrast, $V$. dahliae var. longisporum and the two $V$. dahliae isolates investigated here appeared extremely stable. These are assumed to be homozygous diploids arising as a result of total mitotic nondisjunction or from somatic nuclear fusion in a homokaryotic cell. Further evidence for homozygosity was the observation that all haploid segregants appearing after treatment with $p$ fluorophenylalanine were similar in morphology to the parent isolate. In fact, Tolmsoff (1983) suggested that production of aneuploids from homozygous diploids is a significant source of genetic variability.

Unequivocal demonstration of the parasexual cycle as a major cause of variability in Verticillium species in the wild is difficult, presumably because of its rare and transient nature in most cases, and some workers dispute its relevence. However, when MacNeill \& Chilton (1981) inoculated tomato plants with two distinct prototrophic isolates of Fusarium oxysporum $\mathrm{f}$. sp. lycopersici, many recombinants were recovered. Similarly, Clarkson \& Heale (1985) infected Antirrhinum plants with two haploid complementary diauxotrophic isolates of $V$. albo-atrum from hop and were able to reisolate a stable, pathogenic, prototrophic diploid. Even where diploidy is rare and transient, there may be profound evolutionary potential in terms of genetic recombination for many deuteromycete fungi.

We suggest that the two new strains of $V$. dahliae described here be assigned to $V$. dahliae var. longisporum, a form previously isolated only from horse-radish in Germany.

We thank the SERC and Microbial Resources Ltd (formerly Tate \& Lyle Ltd) for financial assistance via a CASE award to C. W. Jackson during the period when the research was carried out. Thanks are also due to Dr $\mathrm{S}$. Lisansky for helpful discussion.

\section{REFERENCES}

Bergeron, D. \& AL-Aidroos, K. (1982). Haploidization analysis of heterozygous diploids of the fungus Metarhizium anisopliae. Canadian Journal of Genetics and Cytology 24, 643-651.

Burges, H. D. (1981). Microbial Control of Pests and Plant Diseases 1970-1980. London \& New York: Academic Press.

BuXTON, E. W. (1956). Heterokaryosis and parasexual recombination in pathogenic strains of Fusarium oxysporum. Journal of General Microbiology 15, 133 139.
Caten, C. E. \& Day, A. W. (1977). Diploidy in plant pathogenic fungi. Annual Review of Phytopathology 15, 295-318.

Clarkson, J. M. \& Heale, J. B. (1985). Heterokaryon compatibility and genetic recombination within a host plant between hop wilt isolates of Verticillium albo-atrum. Plant Pathology 34, 129-138.

Clutterbuck, A. J. (1969). Cell volume per nucleus in haploid and diploid strains of Aspergillus nidulans. Journal of General Microbiology 55, 291-299.

DAS, A. \& IlzUCK, Z. (1978). Spontaneous segregation 
of a heterozygous diploid of Aspergillus niger. Folia Microbiologica 23, 363-365.

DAY, P. R. (1960). Variation in phytopathogenic fungi. Annual Review of Microbiology 14, 1-16.

Dhillon, S. S., Berlyn, G. P. \& Miksche, J. P. (1977). Requirement of an internal standard for microspectrophotometric measurements of DNA. American Journal of Botany 64, 117-121.

Domsch, K. H., GaMs, W. \& ANDERSON, T.-H. (1980). Compendium of Soil Fungi, pp. 840-841. London \& New York: Academic Press.

Fincham, J. R. S., DAY, P. R. \& Radford, A. (1979). Fungal Genetics, 4th edn. Oxford: Blackwell Scientific Publications.

Fox, D. (1969). Some characteristics of the cold hydrolysis technique for staining plant tissue by the Feulgen reaction. Journal of Histochemistry and Cytochemistry 17, 266-272.

HaLL, R. A. (1980). Laboratory infection of insects by Verticillium lecanii strains isolated from phytopathogenic fungi. Transactions of the British Mycological Society 74, 445-446.

HaLl, R. A. (1981). The fungus Verticillium lecanii as a microbial insecticide against aphids and scales. In Microbial Control of Pests and Plant Diseases, pp. 483-498. Edited by H. D. Burges. London: Academic Press

HaStiE, A. C. (1964). The parasexual cycle in Verticillium albo-atrum. Genetical Research 5, 305-315.

Hastie, A. C. (1970). The genetics of asexual phytopathogenic fungi with special reference to Verticillium. In Root Diseases and Soil-borne Pathogens, pp. 55-62. Edited by T. A. Tousson, R. V. Bega \& P. E. Nelson. Berkeley: University of California Press.

Hastie, A. C. \& Heale, J. B. (1984). Genetics of Verticillium. Phytopathologia mediterranea, 22, 2-3, pp. $130-162$.

Heale, J. B., Gafoor, A. \& Rajasingham, K. C. (1968). Nuclear division in conidia and hyphae of Verticillium albo-atrum. Canadian Journal of Cytology 10, 321-340.

Heale, J. B., Clarkson, J. M. \& Harris, G. P. (1981). Strain specialisation, genetic compatibility and colonisation studies in Verticillium wilt of lucerne and hop. In Abstracts of the 3rd International Verticillium Symposium, Bari, Italy, p. 37.

INGRAM, R. (1968). Verticillium dahliae Kleb. var. longisporum Stark: a stable diploid. Transactions of the British Mycological Society 51, 339-341.

ISAAC, I. (1949). A comparative study of pathogenic isolates of Verticillium. Transactions of the British Mycological Society 32, 137-157.

JaCkson, C. W. \& Heale, J. B. (1983). Protoplast fusion to overcome vegetative incompatibility in Verticillium lecanii parasexual genetics. In Protoplasts 1983. Poster Proceedings, 6th International Protoplast Symposium, Basel, August 12-16, 1983, pp. 318-319. Basel: Birkhauser Verlag.

JaCKson, C. W., Heale, J. B. \& Hall, R. A. (1985). Traits associated with virulence to the aphid Macrosiphoniella sanbornii in eighteen isolates of Verticillium lecanii. Annals of Applied Biology 106, 3948.

Jensen, W. A. (1962). Histochemistry. San Franciso: W. H. Freeman.

Kasyanenko, A. G. \& Portenko, L. G. (1978).
Somatic recombination as a source of new races of cotton Verticillium wilt causal agent. In Genetic Variability of the Wilt-causing Agent and Prospects for Increasing Cotton Wilt Resistance, pp. 107-109. Edited by A. Maksumov. Dushanbe, USSR: Donish Publishing House. (In Russian; English summary).

Leslie, R. \& Parbery, D. G. (1972). Growth of Verticillium lecanii on medium containing sodium fluoride. Transactions of the British Mycological Society 58, 351-352.

MaCNeill, B. H. \& Chilton, S. (1981). Genetic exchange between prototrophic strains of Fusarium oxisporum f. sp. lycopersici. Canadian Journal of Plant Pathology 3, 197-200.

Messias, C. L. \& Azevedo, J. L. (1980). Parasexuality in the deuteromycete Metarhizium anisopliae. Transactions of the British Mycological Society 75, 473-477.

NGA, B. H., TEO, S.-P. \& LIM, G. (1975). The occurrence in nature of a diploid strain of Aspergillus niger. Journal of General Microbiology 88, 364-366.

Pelletier, G. \& Aube, C. (1970). Conidial size and contents in Verticillium as affected by environmental factors. Canadian Journal of Microbiology 16, 213236.

Puhalla, J. E. \& Hummel, M. (1983). Vegetative compatibility groups within Verticillium dahliae. Phytopathology 73, 1305-1308.

ReINKE, J. \& BERTHOLD, G. (1879). Die Zersetzung der Karftoffel durch Pilze. Untersuchungen aus dem botanischen Laboratorium der Universität Göttingen. 1, $1-100$.

Schreiber, L. R. \& Green, R. J. (1966). Anastomosis in Verticillium albo-atrum in soil. Phytopathology 56, $1110-1111$.

Singh, U. P. (1972). Anastomosis and nuclear condition in Cephalosporium coccorum Petch. Mycopathologia et mycologia applicata 48, 167-174.

SMiTH, H. C. (1965). The morphology of Verticillium albo-atrum, V. dahliae and V. tricorpus. New Zealand Journal of Agricultural Research 8, 450-478.

STARK, C. (1961). Das Auftreten der VerticilliumTracheomykosen in Hamburg Gartenbaukulturen. Gartenbauwissenschaft 26, 493-528.

Tinline, R. D. \& MacNeill, B. H. (1969). Parasexuality in plant pathogenic fungi. Annual Review of Phytopathology 7, 147-170.

TolmsofF, W. J. (1972). Diploidization and heritable gene-repression as major source for variability in morphology, metabolism and pathogenicity of Verticillium species. Phytopathology 62, 407-413.

TolmsofF, W. J. (1973). Life cycles of Verticillium species. In Verticillium Wilt of Cotton, pp. 20-38. Publication ARS-S-19, National Cotton Pathology Research Laboratory, Texas, USA.

TOLMSOFF, W. J. (1983). Heteroploidy as a mechanism of variability among fungi. Annual Review of Phytopathology 21, 317-340.

TYPAS, M. A. (1983). Heterokaryon incompatibility and interspecific hybridization between Verticillium albo-atrum and Verticillium dahliae following protoplast fusion and microinjection. Journal of General Microbiology 129, 3043-3056.

Typas, M. A. \& HEALE, J. B. (1976). Heterokaryosis and the role of cytoplasmic inheritance in dark resting structure formation in Verticillium spp. Molecular and General Genetics 146, 17-26. 
Typas, M. A. \& Heale, J. B. (1977). Analysis of ploidy levels in strains of Verticillium using a Coulter counter. Journal of General Microbiology 101, 177180.

Typas, M. A. \& Heale, J. B. (1980). DNA content of germinating spores, individual hyphal cells and resting structure cells of Verticillium spp. measured by microdensitometry. Journal of General Microbiology 121, 231-242.
UPSHALL, B. (1981). Naturally occurring diploid isolates of Aspergillus nidulans. Journal of General Microbiology 122, 7-10.

Williams, P. G. \& Mengden, K. W. (1975). Cytofluorometry of DNA in uredospores of Puccinia graminis f. sp. tritici. Transactions of the British Mycological Society 64, 23-28. 